\title{
METHODS AND OPPORTUNITIES IN THE RESEARCH OF BRONZE AGE COMMUNITIES - THE OUTCOMES OF THE BIOARCHAEOLOGICAL RESEARCH PROGRAMME OF THE MOMENTUM MOBILITY' RESEARCH GROUP (2015-2020)
}

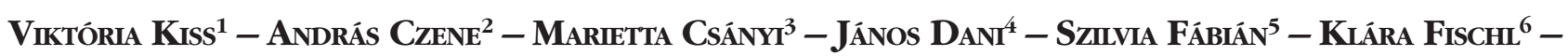
Dániel Gerber ${ }^{7}$ - Julia I. Giblin ${ }^{8}$ - Tamás Hajdu ${ }^{9}$ - Kitti Köhler ${ }^{1}$ - Eszter Melis ${ }^{1}$ - Balázs Gusztáv Mende $^{7}$ - Róbert Patay ${ }^{10}$ - Géza Szabó ${ }^{11}$ - Anna Szécsényi-NagY ${ }^{7}$ - Vajk Szeverényi ${ }^{4}$ - Gabriella Kulcsár ${ }^{1}$ Hungarian Archaeology Vol. 10 (2021), Issue 3, pp. 30-42. https://doi.org/10.36338/ha.2021.3.3

Although there is no textual evidence known from the Bronze Age, written sources describing migrations of later (i.e. Early Medieval) periods effecting the Carpathian Basin were interpreted as instances of cultural and population change which could be comparable with processes that took place during the Bronze Age in the Carpathian Basin. In the past two decades, Eurasian archaeological research received a new impetus to investigate the traces of migrations during prehistory, in collaboration with other disciplines such as isotope geochemistry or archaeogenetics. The current project which commenced in 2015, funded by the 'Momentum Programme' of the Hungarian Academy of Sciences, was set out to investigate the societal changes that had taken place within the boundaries of modern-day Hungary-contemporaneous with the builders of the great pyramids of Egypt and the Greek heroes of the Mycenaean shaft graves - by analysing the settlements, cemeteries and the artefacts recovered from these archaeological sites. The project, for the first time in Hungarian Bronze Age research, employs a range of multidisciplinary methodologies in order to examine the social changes of the period. The present paper is to provide an overview of a particular aspect of this research: the outcomes of the bioarchaeological enquiries with special regards to the general health, mobility and the lifestyle of studied populations.

Keywords: Early and Middle Bronze Age, human remains, bioarchaeology, food consumption, health, mobility

The project entitled From bones, bronzes and sites to society: Multidisciplinary analysis of human mobility and social changes in Bronze Age Hungary (2500-1500 BC) conducted by the 'Momentum Mobility' Research Group examines the societal changes that had taken place during the first half of the Bronze Age that spanned over almost two millenia (2600/2500-800 BC) in the Carpathian Basin. The project's main aim is to better understand the lifestyle, mobility, inequalities, stratification and craft specialisation that existed in Bronze Age societies, drawing on evidence from settlements, cemeteries, including human and animal remains and a range of artefacts (e.g. weapons, tools, ornaments and ceramics). The project is also

\footnotetext{
Eötvös Loránd Research Network, Institute of Archaeology, Research Centre for the Humanities; email: kiss.viktoria@abtk.hu; kohler.kitti@abtk.hu; kulcsar.gabriella@abtk.hu; melis.eszter@abtk.hu

Salisbury Kft.; email: andras.czene@gmail.com

Damjanich János Múzeum; email: dr.csetta@gmail.com

Déri Múzeum; email: dani.janos@derimuzeum.hu; szeverenyi.vajk@derimuzeum.hu

Hungarian National Museum; email: fabian.szilvia@hnm.hu

University of Miskolc; email: fklari@gmail.com

7 Eötvös Loránd Research Network, Institute of Archaeogenomics, Research Centre for the Humanities; email: gerber.daniel@abtk.hu; mende.balazs@abtk.hu; szécsényi-nagy.anna@abtk.hu

8 Quinnipiac University; email: Julia.Giblin@quinnipiac.edu

9 University Eötvös Loránd, Department of Biological Anthropology; email: tamas.hajdu@ttk.elte.hu

10 Ferenczy Múzeumi Centrum; email: robert.patay@gmail.com

11 Wosinsky Mór Múzeum; email: kaladeaa@gmail.com
} 


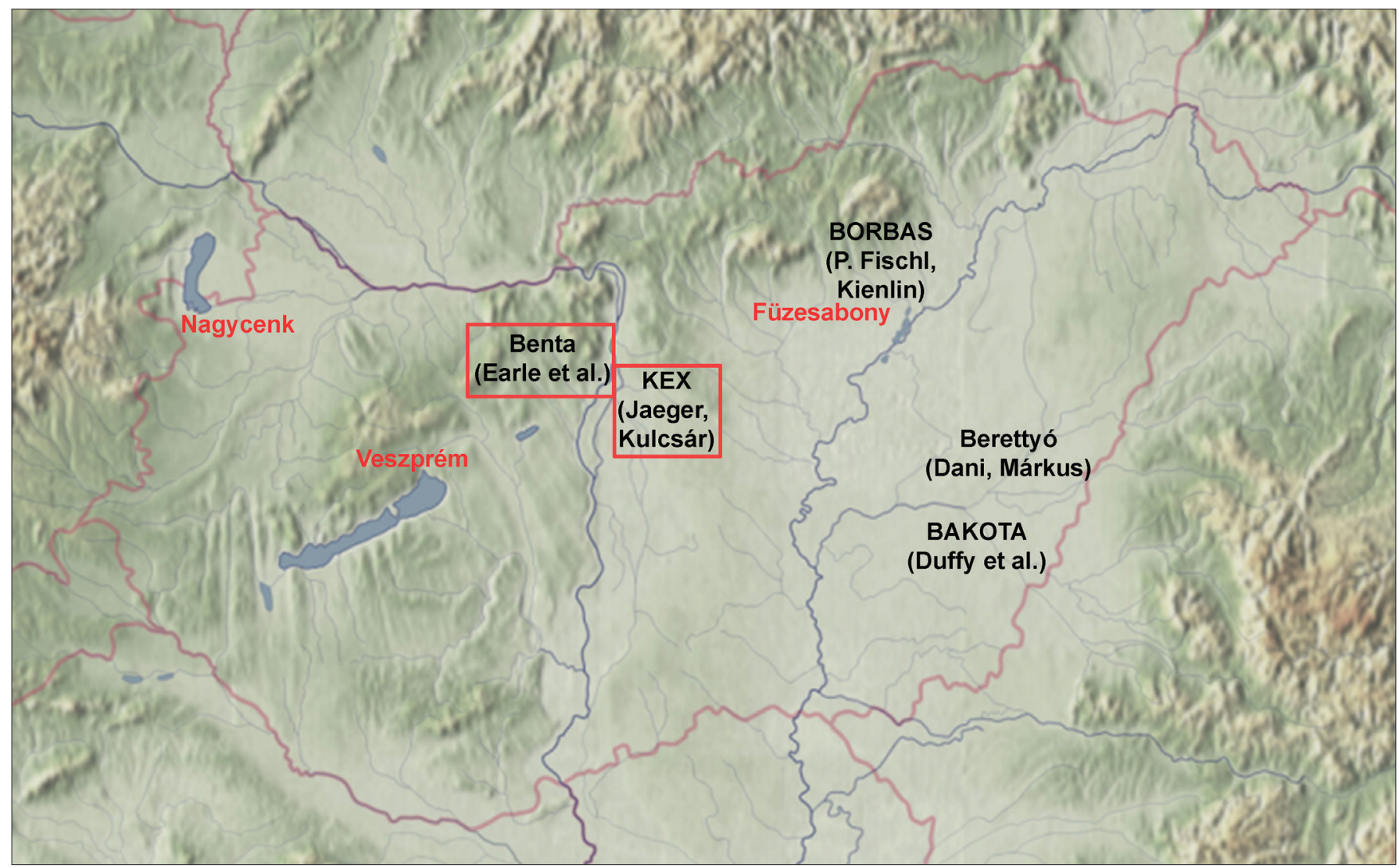

Fig. 1. Bronze Age microregional research projects in Hungary (marked black) and the sample regions of the Momentum Mobility Research Group (marked red)

designed to map out contemporaneous exchange networks of the period such as the 'trade routes' of bronze, gold and amber. Five, previously well-investigated sites and their surrounding microregions were selected within the area of modern-day Hungary (Fig. 1; Central Hungary: Benta Valley and Kakucs microregion, Northeast Hungary: the region of Füzesabony, Transdanubia: the regions of Veszprém and Nagycenk), in order to provide a representative geographical sampling area comparable with Central European cultural complexes during the Bronze Age. In this way, the project is able to contribute to the corpus of microregional research by the detailed study of lesser investigated areas and partially published key sites (cf. EARLE et al. 2014; Kulcsár et al. 2014; SZathmári et al. 2019; Kiss \& KulcsÁr 2020).

From the perspective of bioarchaeology, besides the burials discovered nearby microregional centres, the project has also sampled and analysed the contents of burials at a number of other sites. The exceptional finding circumstances, contexts and preservation of these human remains were able to provide further valuable information on Bronze Age societies (Fig. 2).

Written sources originating from the Migration period (i.e. Early Medieval) describe processes of population change in the area of modern-day Hungary that were thought to be comparable with processes that took place during the Bronze Age of the region. The appearance of new archaeological phenomena in the $3^{\text {rd }}$ millenium has generally been explained by cultural infuences coming from the east (Pit Grave Kurgans/ Yamnaya complex) or from the west (Bell Beaker culture), who brought with them the knowledge of bronze manufacture (BÓNA 1992). The 1970s marked the beginning of a paradigm shift in the interpretation of cultural change by archaeological research as a whole. As opposed to population change or migration, the new approach considered the spread of a particular ceramic style, vessel type or burial tradition across larger swathes of Europe as the outcome of economic, social, spiritual or political processes (for a summary, see: FURHOLT 2021). In the past two decades, archaeological research received a new impetus to identify the traces of migrations during prehistory, in collaboration with other disciplines such as isotope geochemistry and archaeogenetics (BÁNFFY 2013). This groundswell of research brought about numerous publications 


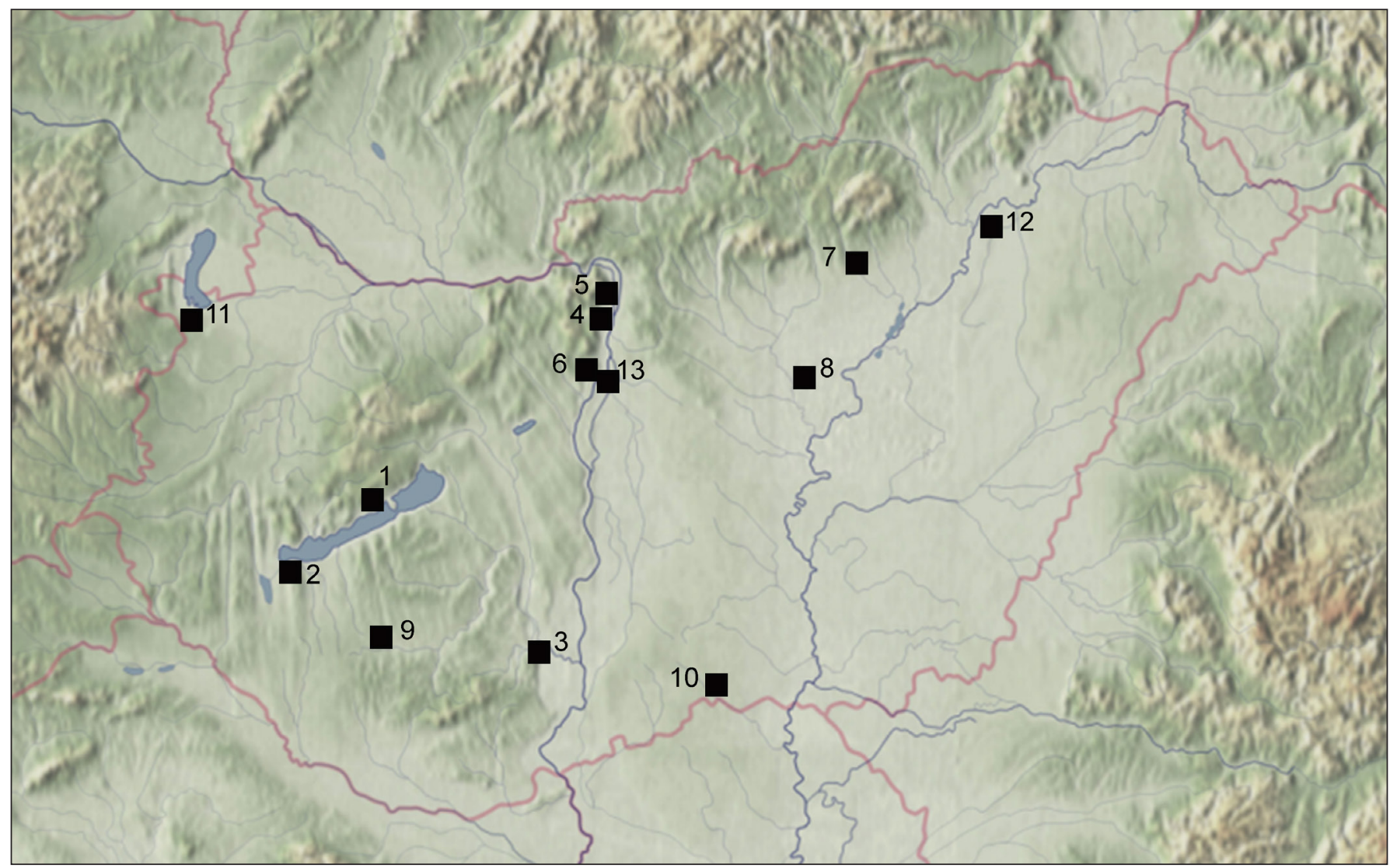

Fig. 2. Major sites for bioarchaeological sampling: 1. Balatonakali, 2. Balatonkeresztúr 3. Bonyhád, 4. Budapest-Békásmegyer, 5. Budakalász, 6. Érd, 7. Füzesabony, 8. Jánoshida, 9. Kaposvár, 10. Kelebia, 11. Nagycenk, 12. Polgár, 13. Szigetszentmiklós

each putting forward an interpretation of Bronze Age mobility and family relations (MitTNIK et al. 2019; SCHROEDER et al. 2019). However, several of these interpretations - specifically the ones relying on genetics data - have received criticism, drawing attention to the pitfalls of certain methodologies. The dialogue also highlighted that a multidisciplinary approach that integrates perspectives from the natural sciences, humanities (history), and social sciences (cultural anthropology, ethnography and sociology) is neccessary in order to model Bronze Age societies (EISENMANN et al. 2018; BRÜCK 2021).

Migration theories remained important in Hungarian research until recently (CsÁNYI 2003; SZABÓ 2017). Alongside these theories the changes in climate and vegetation (and their effects), or economic factors were identified as the possible causes for the tranformation of material culture or the shift in settlement structure (for a summary, see: P. FISCHL et al. 2013). Our research programme employs a range of $21^{\text {st }}$ century multidisciplinary methodologies relying on - besides the traditional approaches of archaeology - the advances of genetics, pathology, absolute dating, and isotope-geochemistry in order to better understand the changes that took place in Bronze Age societies in the region of Hungary.

\section{MOBILITY}

One of the bioarchaeological methods the project employs examines the ratio of strontium and oxygen isotopes in human bones and teeth to pinpoint the geographical location where the given individual was born or grew up. During the course of childhood, strontium and oxygen stable isotopes ${ }^{87} \mathrm{Sr} /{ }^{86} \mathrm{Sr}$ and $\delta^{18} \mathrm{O}$ ) consumed with food and water are integrated into the tooth enamel and bones. By looking at the ratio of strontium and oxygen isotopes present in the bones/teeth of an adult, and by comparing it with the ratio occurring in the region encapsulating the human remains (i.e. background signature), it is possible to infer whether the individual was born and/or grew up locally or migrated from elsewhere. Unfortunately, these comparisons are hindered in regions where the bedrock share similar geological properties (i.e. producing readings akin 
Viktória Kiss et al. • Methods and Opportunities in the Research of Bronze Age Communities
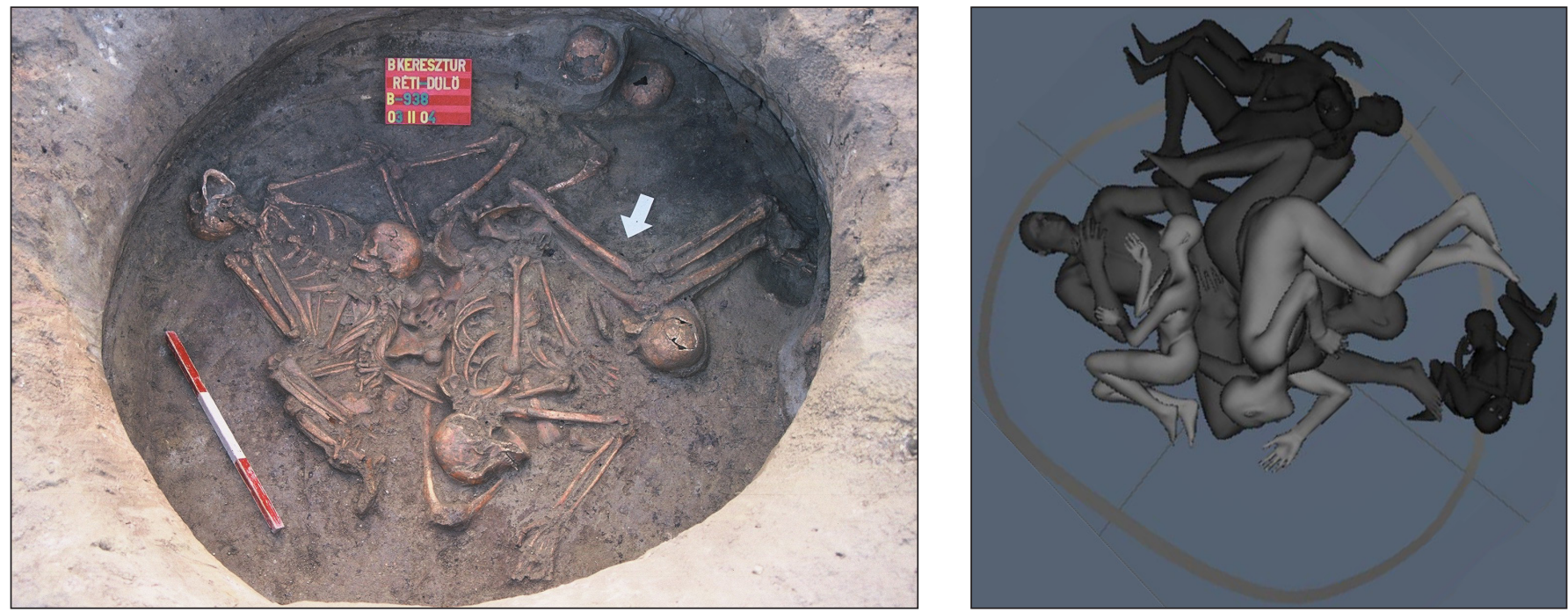

Fig. 3. Balatonkeresztúr-Réti-dülö, a pit burial containing eight individuals (feature B-938) (photo by Szilvia Fábián, 3D reconstruction by Dávid Ringeisen)

to the background signature), but the method can be reliably used in most cases to identify the traces of a mobile lifestyle. In this way, mobility should be understood as a broader term than migration: it can include not only one-way physical migrations but also the tradition of exogamous marriages for instance. Based on the data so far, mobility could be represented by individuals, primarily by women, who perhaps arrived from different geographical regions for the purpose of marriage or by men who died far away from their birthplace as a result of warfare or by individuals who came to utilise the long distance trading networks of the period (Gerling \& Ciugudean 2013; Frei et al. 2015; Price et al. 2019; Cavazzuti \& Arena 2020).

Flexed burials, where individuals were placed on their sides with their legs pulled up in a sleeping or foetal position, accompanied by weapons and ornaments, are well known from the Hungarian Bronze Age. However, the tradition of cremation also began to spread during this period; a practice that resulted in the significant damage of skeletal material and DNA, making physical anthropological and archaeogenetic testing problematic. Throughout the duration of the project our deliberate aim was to include non-normative burials (i.e. inhumations) in the analysis of cremation burial grounds. Since non-normative inhumations were often without grave goods, it was difficult to date and interpret these depositions. 'Irregular', exceptional burials also occurred at settlements, usually also without grave goods (Fig. 3). Besides inhumations, AMS radiocarbon dating was used for the first time on Bronze Age cremations from Hungary, contributing to the already existing absolute chronological sequence (HAJdu et al. 2016; DANI et al. 2019; KIss et al. 2019).

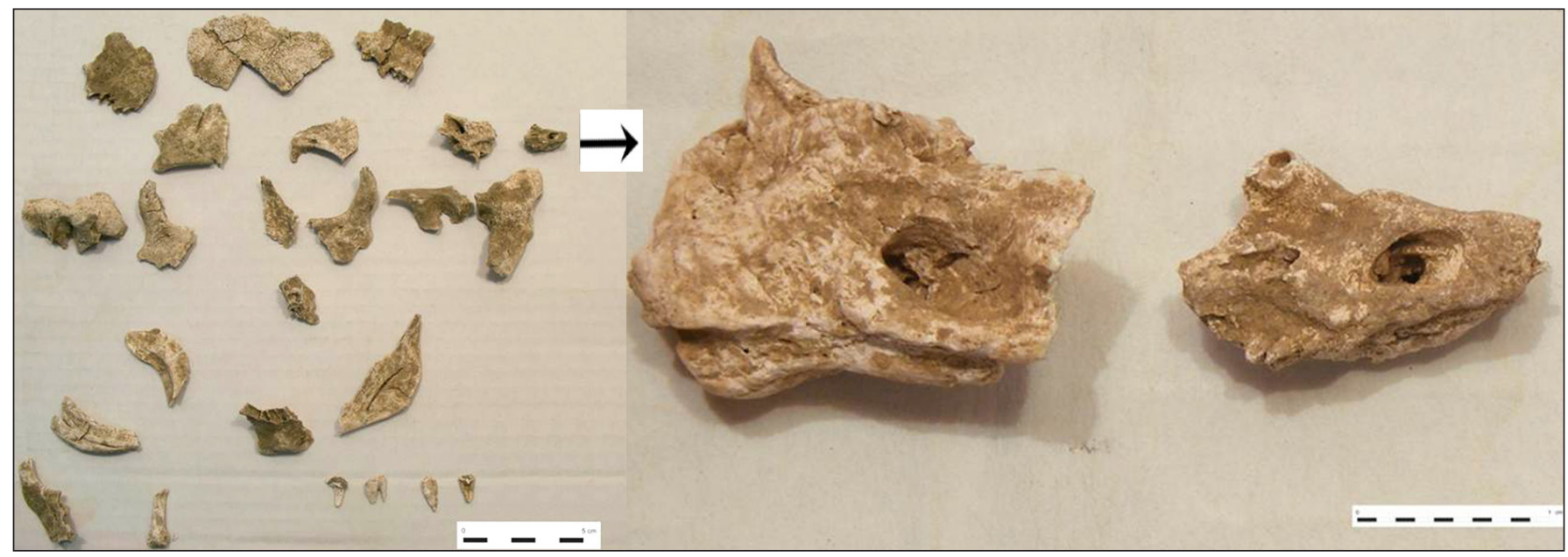

Fig. 4. Remains of an adult woman and a premature infant/foetus from Bonyhád-Biogáz üzem (Biogas factory) grave 80, b: The fragment of the os temporale of the adult woman and the premature infant/foetus (SZABÓ \& HAJDU 2011, after Fig. 4.) 
Strontium isotope tests carried out on molars from inhumations and settlement burials, in collaboration with the universities of Quinnipiac and Yale, confirmed that in several cemeteries from Hungary during the Early and Middle Bronze Age there was no evidence for the presence of immigrants, while among other communities sampled from this region the ratio of non-locals was as high as $40 \%$ in some cases (GIBLIN et al. 2019). Examinations conducted in recent years have shown that in the case of cremation burials, where teeth often completely desintegrated during the mortuary process, the sampling of the petrous bone (os temporale; Fig. 4) can provide further evidence (CAvazzuti \& ARENA 2020). The first strontium isotope investigations on cremation burials from Bronze Age Hungary were carried out (among others) on 29 individuals from the second largest cremation cemetery of the Middle Bronze
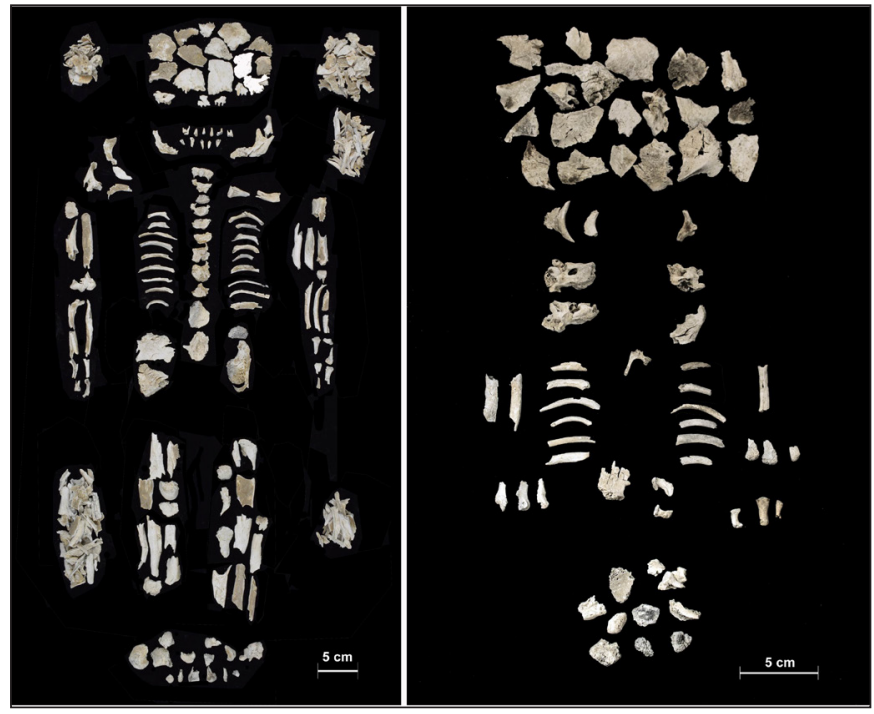

Fig. 5. Cremated bones of an adult female and her twin foetuses of 7-8 months from Szigetszentmiklós-Ürgehegy grave 241 (CAVAZZUTI et al. 2021, Fig. 4) Age Vatya culture: Szigetszentmiklós-Ürgehegy (525 burials in total), in cooperation with the University of Bologna and the ICER Laboratory of ATOMKI Debrecen (Eötvös Loránd Research Network), also supported by the Distinguished Guest Scientists Fellowship programme of the Hungarian Academy of Sciences. The results provided a rare glimpse into the life story of a 25-35 year-old, presumably non-local woman who died while 7-8 months pregnant with twins, cremated and buried (Fig. 5). Above data indicate that similarly to the Bronze Age communities in Central or Western Europe (MitTNiK et al. 2019) the rate of mobility could have been significant among groups who lived during the first thousand years of the Bronze Age in Hungary. The ratio of women was higher among the immigrants, but non-local men and children also occur in the dataset. Based on this, it is possible to assume that men from local communities often chose wives from groups living further afield; but the presence of entire non-local families should be considered as well (Giblin et al. 2019; CAVAZZuTI et al. 2021).

Whole genome sequencing carried out on the Early Bronze Age Bell Beaker burials from Hungary by the Laboratory of Archaeogenetics of the Institute of Archaeology, Research Centre for the Humanities, Eötvös Loránd Research Network (from 2021 the Institute of Archaeogenomics) in collaboration with the Department of Genetics of the Harvard Medical School provided further important information regarding mobility. The groups of the Bell Beaker culture in Hungary, that also spread across the regions of Western and Central Europe during the Early Bronze Age, has long been associated with some definitive physical anthropological traits (such as taurid skulls; K. ZOFFMANN 2000; KöHLER 2011). Stable isotope analyses conducted on Bell Beaker human remains point towards an immigrant community as well (KULCSÁR 2011, with further references). The genomics investigations from a number of different European regions carried out on a dataset of archaic DNA sequences of nearly 400 individuals who lived during the Early Bronze Age period were co-authored and the results published by members of our project. This evidence helped to define the roles non-local communities from the Eastern steppe played in the genetic histories of Central and Western Europe. The DNA analyses have shown that individuals buried in cemeteries dating to 2500-2200 BC from the surrounding regions of Budapest, in some cases were descendants of Neolithic communities. However, several individuals from these burials can (sometimes in $75 \%$ of their genomic characteristics) be linked to communities originating from the Eastern steppe region (OlaldE et al. 2018). Genetic and isotopic examinations confirm the heterogenity that has been demonstrated by previous studies carried out on the archaeological material excavated at large Bell Beaker burial sites. According to these, non-locals associated with characteristic Western European vessel types and dress ornaments, and local individuals (occasionally exhibiting Balkan influences) lived peacefully together. This and the period 


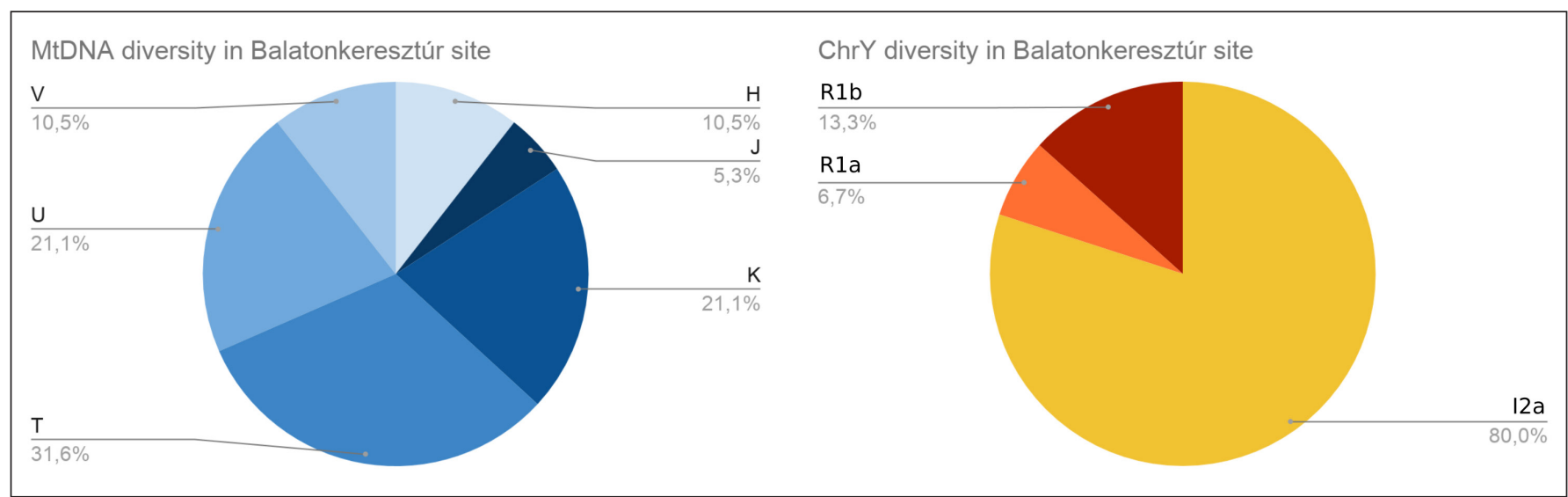

Fig. 6. mtDNA and Y chromosome haplogroups or the ratio of maternal and paternal lineages in the genetic dataset of Balatonkeresztúr-Réti-dülö from the Bronze Age (GERBER, SZÉCSÉNYI-NAGY \& KISS 2021, 5. ábra)

directly following the Early Bronze Age is when the foundations of Europe's genetic makeup are being laid down; the three main genetic components were already present: 1) local mesolithic hunter-gatherers, 2) neolithic agriculturalist immigrants and 3) newcomer pastoral groups from the Eastern steppe. The mixing of these three key genetic components resulted in regional differences in the genetic character of communities such as in the case of the Füzesabony culture in Northeast Hungary, and the groups settled in Transdanubia towards the end of the Early Bronze Age and during the Middle Bronze Age (SzÉCsÉNYINAGY et al. 2021). The examinations carried out on human remains from the vicinity of Balatonkeresztúr associated with the Kisapostag/Earliest Transdanubian Encrusted Pottery culture show a clear genetic link between the subsequent populations (Transdanubian Encrusted Pottery culture), as it has been previously observed given the similarities in their ceramic material (Fig. 6) (Szabó \& HaJdu 2011; Kiss 2012; Gerber et al. 2020; GERBER, SZÉCSÉNYI-NAGY \& Kiss 2021).

\section{FOOD CONSUMPTION}

Stable carbon and nitrogen isotope analyses carried out on human and animal bones can help to identify crucial details regarding the lifestyle and diet of Bronze Age populations and their livestock. Data from the Neolithic period suggest that with the spread of agriculture, European communities consumed more cereal varieties and less meat, resulting in overall poorer health which slowly began to improve during the Bronze Age (MARCINIAK et al. 2021). Nitrogen isotope examinations conducted on human remains from the western regions of Central Europe have shown that individuals who belonged to the highest ranks of society (such as the chief buried in the tumulus burial of Leubingen in Germany) and men in general consumed more meat (KNIPPER et al. 2015). The latest carbon isotope investigations have demonstrated that besides $\mathrm{C}_{3}$ plants such as barley and other
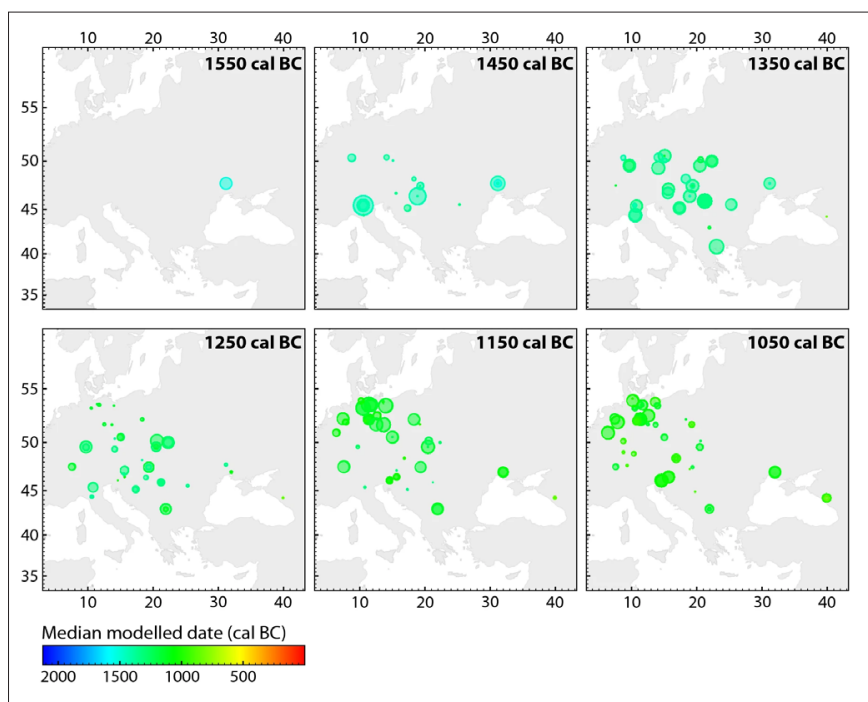

Fig. 7. The distribution of millet consumption in Bronze Age Europe (FILIPOVIĆ et al. 2020, Fig. 4) wheat species, millet (quickly following its first European appearance in the Black Sea region) also became part of a staple diet in the Carpathian Basin in the $16^{\text {th }}$ century BC (Fig. 7; GAMARRA et al. 2018; Filipović et al. 2020). Published evidence for the consumption of millet can be completed by the cemetery of Jánoshida associated with the Tumulus culture, examined by our team (GIBLIN et al. 2019). In some regions it was even 
Viktória Kiss et al. $\cdot$ Methods and Opportunities in the Research of Bronze Age Communities

possible to show that millet had been grown primarily as fodder for pigs, thus the ratio of carbon isotope $\delta^{13} \mathrm{C}$, which is linked directly to $\mathrm{C}_{4}$ plants such as millet, increased in human remains as a result of the consumption of pork meat (CAVAZZUTI \& AlBERTA 2020). The genetic testing of human remains dating to the Early and Middle Bronze Age indicated high levels of lactose intolerance, suggesting that the consumption of cow's milk only became prevalent much later than expected, long after the spread of agriculture (ALLENTOFT et al. 2015). According to recent data, children were generally breastfed until the age of 2 or 3 , sometimes up to the age of 4, and following weaning, periods of nutritional stress were not uncommon during infancy and childhood. Analyses of small, spouted vessels found in several Late Bronze Age burials, have proven these objects to be feeding vessels filled with milk products derived from ruminants (DunNE et al. 2019).

\section{LIFESTYLE AND DISEASES}

Palaeopatholocial analyses carried out on human remains can identify certain traits linked to lifestyle (strenuous, repetitive physical work for instance), disease or injury. Beside the high rate of infant mortality (generally measured around $20-30 \%$, although in the cemetery of Jánoshida this rate was even higher: $65 \%$ ), the leading cause of death in women was likely due to the complications of pregnancy, childbirth and post-partum fever (Hajdu 2008; K. Zoffmann 2015; Rebay-Salisbury et al. 2018; Melis et al. 2020). The examination of teeth show signs of enamel hypoplasia (disrupted formation of the enamel) which indicate periods of considerable malnourishment or a duration of illness with high fever, while porosities detected on the cranial vault (cribra orbitalia) imply chronic anemia (iron deficiency); a trait that occurred regularly on human remains from the Bronze Age (Fig. 8). In some cases individuals with a dislocated hip or some form of paralysis also lived well into adulthood, which illustrate that these disabilities were tolerated by Bronze Age societies (KöHLER 2007; KöHLer 2011; SZEVERÉNyI et al. 2020; MARCINIAK et al. 2021).

Strenuous physical work evidenced on the condition of the spine, arthritis, and herniated discs/vertebrae appear widely on Bronze Age human remains excavated in the Carpathian Basin. Traits linked to hard physical activity were detected on bones that belonged to members of the elite, as well as on skeletons accompanied by few or no grave goods. The most commonly occurring conditions were degenerative joint diseases, spinal or vertebral diseases, periostitis (inflammation of the bone membrane) or enthesitis (inflammation of the attachment of the tendon or ligament) of the knee or heel resulting in the formation of bone spurs (KöHLER 2007; HAJDU 2008; Porčić \& Stefanović 2009; SzeVerényi et al. 2020).

Epidemic illnesses effecting the bones, such as infectious respiratory diseases (and the inflammations these can induce on the bones) can be observed in several cases in our dataset (Fig. 9; SzEVERÉNYI et al. 2020). Within the framework of international

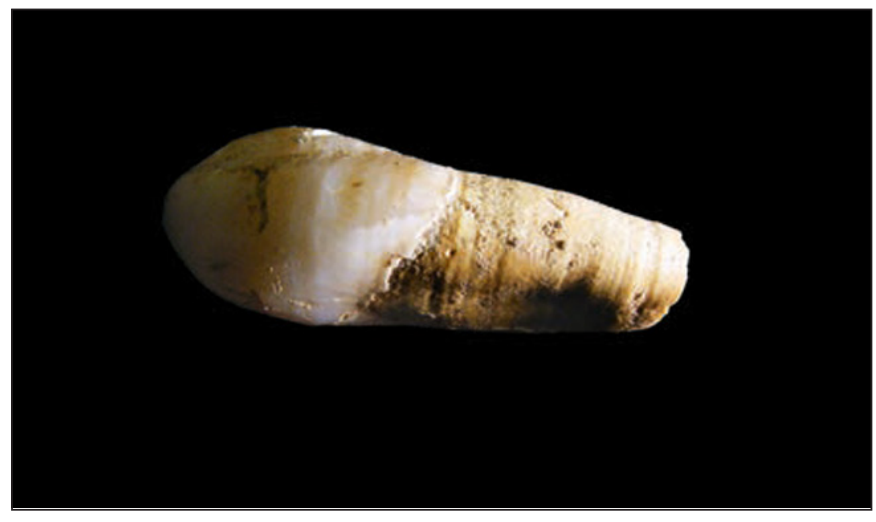

Fig. 8. Enamel hypoplasia on the tooth of a child aged 8-10 from Érd-Hosszúföldek feature no. 207/661 (SZEVERÉNYI et al. 2020, Fig. 16)

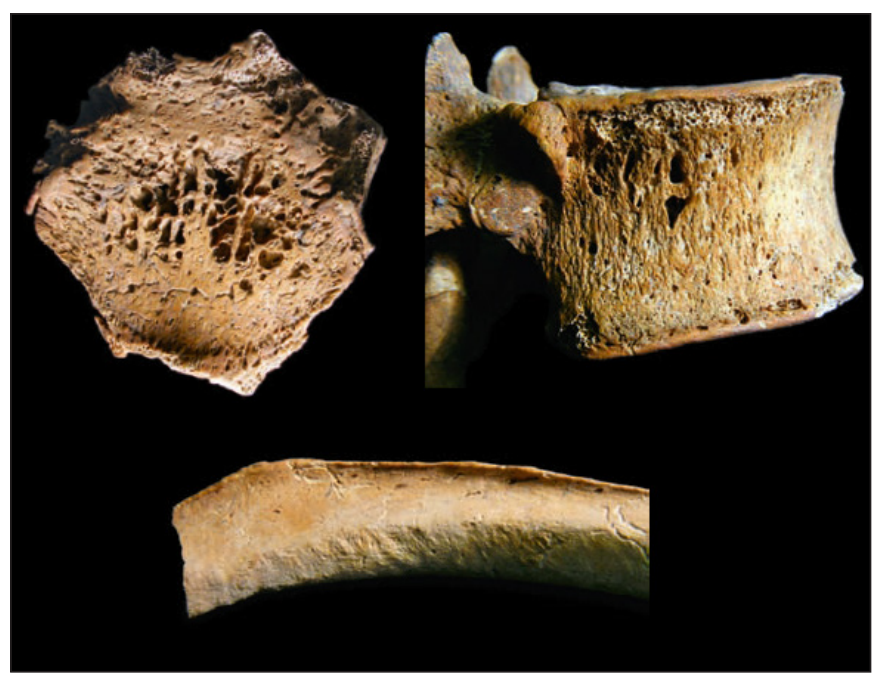

Fig. 9. Hypervascularisation ( $a-b)$ and healed pleurisy (c) indicating a serious infection (a respiratory infection, possibly tuberculosis) detected on the vertebra and rib of a 20-24 year old female, Érd-Hosszúföldek feature 207/662 (SZEVERÉNYI et al. 2020, Fig. 17). 


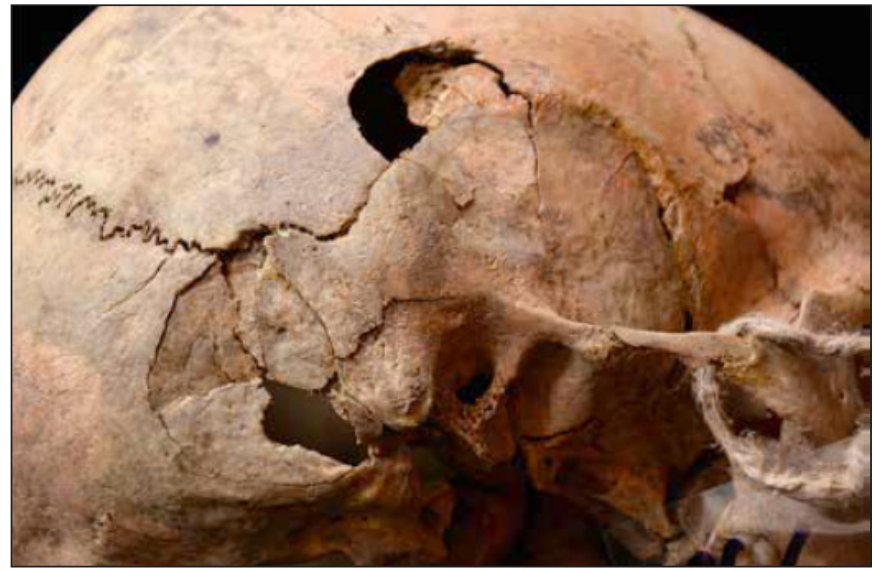

Fig. 10. Perimortem trauma on a skull of a child aged 4-5, Érd-Hosszúföldek feature 806 (SZEVERÉNYI et al. 2020, Fig. 18)

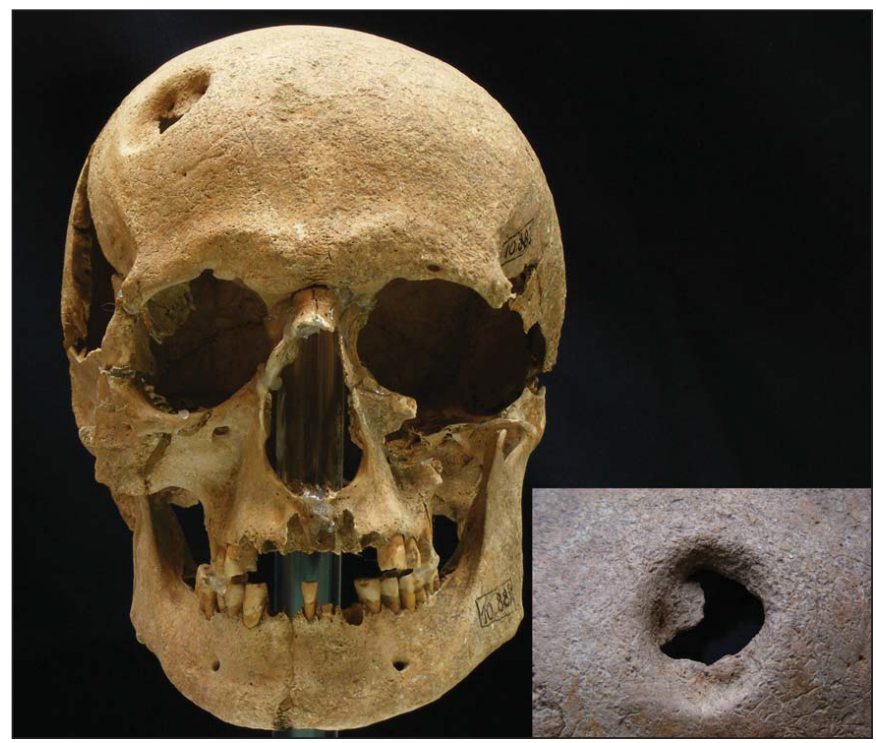

Fig. 11. Partially healed trauma on a skull of an adult male from Füzesabony-Pusztaszikszó grave 8

(SZEVERÉNYI \& KISS 2020, Fig. 4.7)

2014; SzeVerénYI et al. 2020). Signs of serious injuries were also detected on the skeletons known from different geographical regions: at the site of Füzesabony-Pusztaszikszó associated with the Middle Bronze Age Füzesabony culture - on the skull of an adult male a partially healed head trauma was observed (Fig. 11; HAJdu 2008; SZEVERÉNYI \& KisS 2020). With the integration of stable isotope and aDNA data it is possible to conclude that in some cases local and non-local individuals deposited in settlement pits of the period were family members, while in other instances the deceased were not related (Giblin et al. 2019; GERBER et al. 2019). By these complex analyses we are able to glimpse into the ritual traditions that were practiced for a long time across many different regions. collaborations it is now possible to investigate such epidemics (e.g. leprosy, plague) using molecular biological tests on Bronze Age examples as well (RASMUSSEN et al. 2015). Just to mention one specimen from Hungary: evidence for hepatitis B virus was detected on the remains of an adult male dating to the Early Bronze Age Nagyrév culture (2120 1910 BC) excavated at Százhalombatta-Földvár tell site (MüHLEMAnN et al. 2018, Table 1).

Bioarchaeological methods can provide further crucial evidence, especially in the case of non-normative settlement burials, where the archaeological observations and finds offer limited opportunities for interpretation. During the rescue excavation carried out prior to the construction of motorway M6 at Érd-Hosszúföldek, the remains of 36 individuals were discovered from altogether 24 pits dating to the Late Nagyrév and Early Vatya period spanning over 500 years (between 2000 and 1450 BC) according to the absolute ${ }^{14} \mathrm{C}$ dates. The remains of men, women and children showed signs of nutritional stress and some of the aforementioned diseases (Figs 8-9), along with traces of violent trauma, such as a perimortem head injury (Fig. 10; EARLE et al.

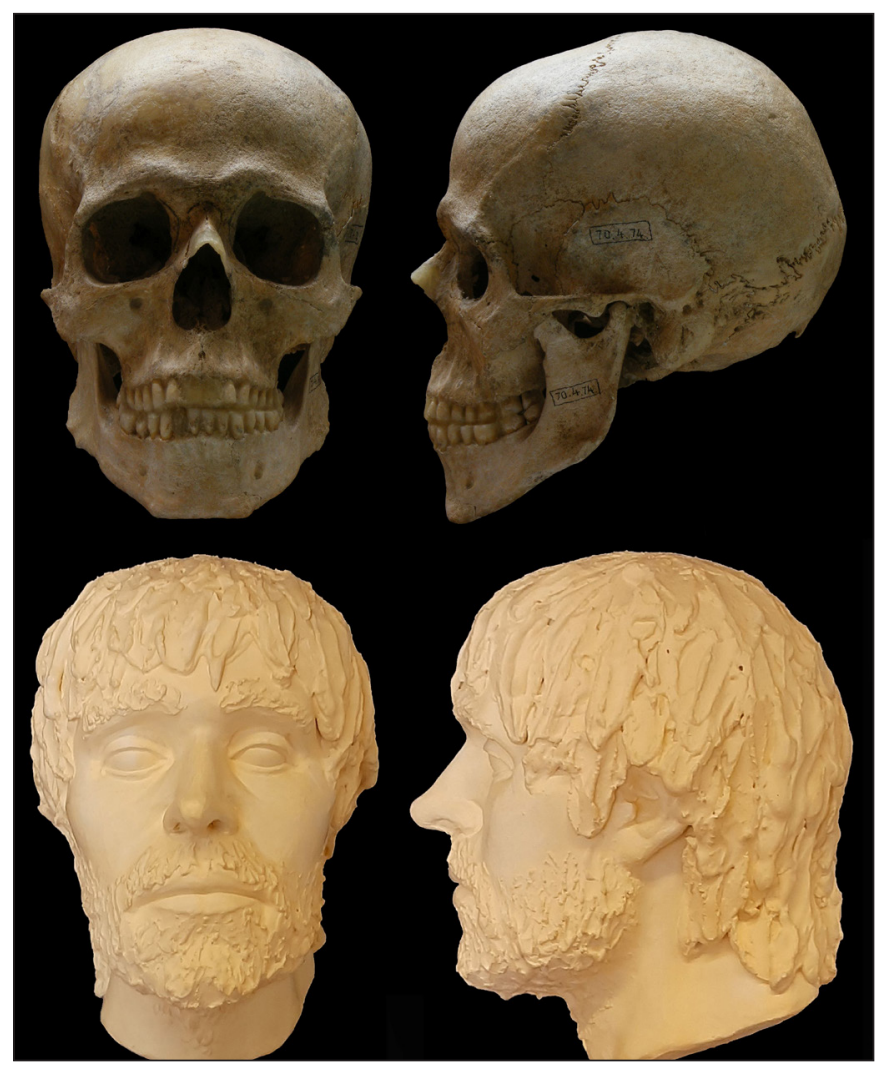

Fig. 12. The skull and facial reconstruction of a Bronze Age adult man from Tiszafüred-Majoroshalom grave D240 (after KUSTÁr et al. 2020) 
Viktória Kiss et al. $\bullet$ Methods and Opportunities in the Research of Bronze Age Communities

With the latest bioinformatic examinations it is possible to reconstruct details of phenotypes (the physical characteristics of individuals) such as eye and hair colour, or skin tone. The investigation of phenotypes has begun on the dataset from Balatonkeresztúr dating to the $3^{\text {rd }}$ and $2^{\text {nd }}$ millenia $\mathrm{BC}$, where along normative inhumations the skeletal remains of eight individuals came to light from a pit (Fig. 3; FÁBIÁN 2007; KöHLER 2007; KIss 2019; Gerber et al. 2020). Based on this evidence, the first facial reconstruction of a Bronze Age man from Hungary (Fig. 12; KusTÁR et al. 2020) will soon be followed by further reconstructions completed by genetic data.

The above described range of bioarchaeological research methodologies provide an opportunity for gaining new insight into how Bronze Age societies might have worked. Investigations of child burials have shown that children were considered as self-standing individuals of the community by the age of 3 , while the transition into adulthood took place sometime between the age of 7 and 14 (MeLis et al. 2020). The physical anthropological examinations of women buried with their foetuses or their infants, and the genetic and stable isotope tests carried out on these remains suggest that girls were married around the age of 13-15, and started a family often far away from their birthplace (ReBAY-SALisBury et al. 2018; MitTNiK et al. 2019; CAVAzZUTI et al. 2021). Evidence for strenuous and repetitive physical work is present on the skeletal remains of both sexes. The appearence of individuals in the dataset with congenital diseases, serious injuries or illnesses effecting their muscoskeletal system who died well into their adulthood imply that Bronze Age societies most likely had been tolerant and supportive of such disabilities. Besides, we have to bear in mind that this is the beginning of the outlined analyses, and the future of Bronze Age archaeology still holds huge prospects thanks to bioarchaeological research.

\section{REFERENCES}

Allentoft, M. E., Sikora, M., Sjögren, K-G., Rasmussen, S. \& Rasmussen, M. et al. (2015). Population genomics of Bronze Age Eurasia. Nature 522, 167-172. https://doi.org/10.1038/nature14507

Bánffy, E. (2013). German-Hungarian bioarchaeological research project in the Archaeological Institute of the Research Centre for the Humanities, Hungarian Academy of Sciences. Hungarian Archaeology 2 (2) [2013 Summer], 1-6.

Bóna, I. (1992). Bronzezeitliche Tell-Kulturen in Ungarn. In W. Meier-Arendt(Hrsg.): Bronzezeit in Ungarn. Forschungen in Tell-Siedlungen an Donau und Theiss (pp. 9-42). Frankfurt am Main: Stadt Frankfurt Dez. Kultur u. Wissenschaft.

Brück, J. (2021). Ancient DNA, kinship and relational identities in Bronze Age Britain. Antiquity 95 (379), 228-237. https://doi.org/10.15184/aqy.2020.216

Cavazzuti, C. \& Arena, A. (2020). The bioarchaeology of social stratification in Bronze Age Italy. Arheo 37, 69-105.

Cavazzuti, C., Hajdu, T., Lugli, F., Sperduti, A., Vicze M. \&Horváth, A. et al. (2021). Human mobility in a Bronze Age Vatya 'urnfield' and the life history of a high-status woman. PlosONE 16 (7), e0254360. https:// doi.org/10.1371/journal.pone.0254360

Csányi, M. (2003). The Tumulus culture: invaders from the west. In Zs. Visy (ed-in-chief), Hungarian Archaeology at the Turn of the Millennium (pp. 161-163). Budapest: Hungarian National Museum. 
Viktória Kiss et al. $\bullet$ Methods and Opportunities in the Research of Bronze Age Communities

Dani, J., Köhler, K., Kulcsár, G., Major, I., Melis, E. \& Patay, R. et al (2019). Case studies on the radiocarbon dating of Bronze Age cremation burials in Hungary. In N. Palincas \& C. Ponta (eds): Bridging Science and Heritage in the Balkans: Studies in archaeometry, cultural heritage restoration and conservation. Proceedings of the Fifth Balkan Symposium of Archaeometry 2016, Sinaia, Romania (pp. 29-37). Oxford: Archaeopress.

Dunne, J., Rebay-Salisbury, K., Salisbury, R. B., Frisch, A., Walton-Doyle, C. \& Evershed, R. P. (2019). Milk of ruminants in ceramic baby bottles from prehistoric child graves. Nature 574 (7777), 246-248. https://doi.org/10.1038/s41586-019-1572-x

Earle, T. K., Kulcsár, G., Kiss, V., Serlegi, G. \& Szeverényi, V. (2014). Recent results from the Bronze Age research into the Benta Valley. Hungarian Archaeology 3 (2) [2014 Summer], 1-5.

Eisenmann, S., Bánffy, E., van Dommelen, P., Hoffmann, K., Maran, J. \& Lazaridis, J. et al. (2018). Reconciling material cultures in archaeology with genetic data: The nomenclature of clusters emerging from archaeogenomic analysis. Nature Scientific Reports 8, art. no. 13003. https://doi.org/10.1038/s41598$\underline{018-31123-\mathrm{Z}}$

Fábián, Sz. (2007). Öskori tömegsír Balatonkeresztúr-Réti-dűlő lelőhelyről - A Prehistoric mass grave at Balatonkeresztúr-Réti-dülő. Somogyi Múzeumok Közleményei 17 (A), 79-88.

Filipović, D., Meadows, J., Corso, M. D., Kirleis, W., Alsleben, A. \& Akeret, Ö. et al. (2020). New AMS ${ }^{14} \mathrm{C}$ dates track the arrival and spread of broomcorn millet cultivation and agricultural change in prehistoric Europe. Nature Scientific Reports 10, art. no. 13698. https://doi.org/10.1038/s41598-020-70495-Z

P. Fischl, K., Kiss, V., Kulcsár, G. \& Szeverényi, V. (2013). Transformations in the Carpathian Basin around 1600 BC. In H. Meller (ed.), 1600 BC - Cultural Change in the Shadow of the Thera-Eruption? (pp. 355-372). Halle (Saale): Landesamt für Denkmalpflege und Archäologie Sachsen-Anhalt-Landesmuseum für Vorgeschichte.

Frei, K. M., Mannering, U., Kristiansen, K., Allentoft, M. E., Wilson, A. S. \& Skals, I. et al. (2015). Tracing the dynamic life story of a Bronze Age Female. Nature Scientific Reports 5, art. no. 10431. https://doi. org/10.1038/srep10431

Furholt, M. (2021). Mobility and social change: Understanding the European Neolithic period after the archaeogenetic revolution. Journal of Archaeological Research. https://doi.org/10.1007/s10814-020$\underline{09153-\mathrm{X}}$

Gamarra, B., Howcroft, R., McCall, A., Dani, J., Hajdú Zs. \& Nagy, E. Gy. et al. (2018). 5000 years of dietary variations of prehistoric farmers in the Great Hungarian Plain. PLoS ONE 13 (5), e0197214. https:// doi.org/10.1371/journal.pone.0197214

Gerber, D., Székely, O., Szeifert, B., Egyed, B., Ari, E. \& Köhler, K. et al. (2020). Inferences on origin and social organisation of Early and Middle Bronze Age communities lived in the western Carpathian Basin. In Kleinová, K. (ed.), EAA 2020 Virtual 24-30 August. \#Networking. 26th EAA Virtual Annual Meeting. Abstract Book (pp. 99-100). Prague: EAA.

Gerber, D., Szécsényi-Nagy, A. \& Kiss, V. (2021). Öskori tömegsír a Balaton-partról. MTA Archeogenomikai Intézet. https://agi.abtk.hu/hu/hirek/oskori-tomegsir-a-balaton-partrol (Accessed 25.10.2021) 
Viktória Kiss et al. $\bullet$ Methods and Opportunities in the Research of Bronze Age Communities

Gerling, C. \& Ciugudean, H. (2013). Insights into the Transylvanian Early Bronze Age using strontium and oxygen isotope analysis: A pilot study. In V. Heyd, G. Kulcsár \& V. Szeverényi (eds), Transitions to the Bronze Age. Interregional Interactions and Socio-Cultural Change in the Third Millennium BC Carpathian Basin and Neighbouring Regions (pp. 181-202). Budapest: Archaeolingua.

Giblin, J., Ayala, D., Czene, A., Csányi, M. Dani, J. \& Endrődi, A. et al. (2019). Bronze Age burials from the Carpathian Basin: New isotope results (poster). SAA 84th Annual Meeting, Albuquerque, New Mexico, U.S., 2019. April 10-14. Program book (p. 100). Albuquerque.

Hajdu, T. (2008). A késő-bronzkori halomsíros kultúra Jánoshida-Berek lelőhelyen feltárt temetőjének embertani vizsgálata - Anthropological examination of the Late Bronze Age cemetery of Tumulus culture from Jánoshida-Berek. Anthropologiai Közlemények 49, 3-20.

Hajdu, T., György-Toronyi, A., Pap, I., Rosendahl, W. \& Szabó, G. (2016). The chronology and meaning of the Transdanubian encrusted pottery decoration. Prähistorische Zeitschrift 91 (2), 353-368.

Kiss, V. (2012). Middle Bronze Age Encrusted Pottery in Western Hungary. Varia Archaeologica Hungarica 27. Budapest: Archaeolingua - MTA Régészeti Intézet.

Kiss V. (2019). Megtestesült bronzkor. In G. Ilon (ed.), Régészeti nyomozások 2.0. (pp. 111-120). Budapest: Martin Opitz.

Kiss, V., Csányi, M., Dani, J., P. Fischl, K., Kulcsár, G. \& Szathmári, I. (2019). Chronology of the Early and Middle Bronze Age in Hungary: New results. In P. Pavúk (ed.), Reinecke's Heritage. Terminology, Chronology and Identity in Central Europe Between 2300 and 1600 BC. Proceedings of the Humboldt Kolleg 12-15. June 2017, Křtiny, Czech Republik (pp. 173-197). Studia Hercynia 23. Prague: Alexander von Humboldt Foundation.

Kiss, V. \& Kulcsár, G. (2020). 'Europe without walls': new directions of Bronze Age research in Hungary. In $\mathrm{K}$. Šabatová et al. (eds), Bringing Down the Iron Curtain. Paradigmatic Change in Research on the Bronze Age in Central and Eastern Europe? (pp. 129-138). Summertown: Archaeopress. https://doi.org/10.2307/j. ctv10crdp4.12

Knipper, C., Held, P., Fecher, M., Nicklisch, N., Meyer, C. \& Schreiber, H. et al. (2015). Superior in life - superior in death: Dietary distinction of central European prehistoric and medieval elites. Current Anthropology 56, 579-589. http://dx.doi.org/10.1086/681536

Köhler, K. (2007). Öskori tömegsír embertani leletei Balatonkeresztúrról -Physical anthropological analysis of a Prehistoric mass grave at Balatonkeresztúr. Somogyi Múzeumok Közleményei 17, 79-88.

Köhler, K. (2011). A harang alakú edények népe Szigetszentmiklós-Felsö-Ürge hegyi dülö lelöhelyen feltárt temetőjének embertani vizsgálati eredményei. Anthropologiai Közlemények 52, 55-76.

Kulcsár, G. (2011). Untangling the Early Bronze Age in the Middle Danube valley. In Gy. Kovács \& G. Kulcsár (eds), Ten Thousand Years along the Middle Danube. Life and Early Communities from Prehistory to History (pp. 179-210). Varia Archaeologica Hungarica 26. Budapest: Archaeolingua.

Kulcsár, G., Jaeger, M., Kiss, V., Márkus, G., Müller, J. \& Pető, Á. et al. (2014). The beginnings of a new research program. Hungarian Archaeology 3 (4) [2014 Winter], 1-7. 
Viktória Kiss et al. $\bullet$ Methods and Opportunities in the Research of Bronze Age Communities

Kustár, Á., Hajdu, T., Fülöp, K. \& Kiss, V. (2020). Arcok a bronzkorból. Határtalan Régészet 3, 30-33.

Marciniak, S., Bergey, Ch. M., Silva, A. M., Hałuszko, A., Furmanek, M. \& Veselka, B. et al. (2021). An integrative skeletal and paleogenomic analysis of prehistoric stature variation suggests relatively reduced health for early European farmers. BioRxiv preprint 2021 March, https://doi.org/10.1101/2021.03.31.437881

Melis, E., Hajdu, T., Köhler, K., \& Kiss, V. (2020). Children in the territory of Western Hungary during the Early and Middle Bronze Age: the recognition of developmental stages in the past. In K. RebaySalisbury \& D. Pany-Kucera (eds), Ages and Abilities: The Stages of Childhood and their Social Recognition in Prehistoric Europe and Beyond (pp. 84-106). Childhood in the Past Monograph 9. Oxford: Archaeopress.

Mittnik, A., Massy, K., Knipper, C., Wittenborn, F., Pfrengle, S. \& Carlichi-Witjes, N. et al. (2019). Kinshipbased social inequality in Bronze Age Europe. Science 366, 731-734. https://doi.org/10.1126/science. $\underline{\operatorname{aax} 6219}$

Mühlemann, B., Jones, T. C., Damgaard, P., Allentoft, M. E., Shevnina, I. \& Logvin, A. et al. (2018). Ancient hepatitis B viruses from the Bronze Age to the Medieval period. Nature 557, 418-423. https://doi. org/10.1038/s41586-018-0097-Z

Olalde, I., Brace, S., Allentoft, M. E., Armit, I., Kristiansen, K. \& Rohland, N. et al. (2018). The Beaker phenomenon and the genomic transformation of Northwest Europe. Nature 555 (7695) 190-196. https:// doi.org/10.1038/nature25738

Porčić, M. \& Stefanović, S. (2009). Physical activity and social status in Early Bronze Age society: The Mokrin necropolis. Journal of Anthropological Archaeology 28 (3), 259-273. http://dx.doi.org/10.1016/j. jaa.2009.06.001

Price, T. D., Frei, R., Brinker, U., Lidke, G., Terberger, T. \& Frei, K. M. et al. (2019). Multi-isotope proveniencing of human remains from a Bronze Age battlefield in the Tollense Valley in northeast Germany. Archaeological and Anthropological Sciences 11, 33-49. https://doi.org/10.1007/s12520-017-0529-y

Rasmussen, S., Allentoft, M. E., Nielsen, K., Orlando, L., Sikora, M. \& Sjögren, K.-G. et al. (2015). Early divergent strains of Yersinia pestis in Eurasia 5,000 years ago. Cell 163, 571-582. https://doi.org/10.1016/j. cell.2015.10.009

Rebay-Salisbury, K., Pany-Kucera, D., Spannagl-Steiner, M., Kanz, F., Galeta, P. \& Teschler-Nicola, M. et al. (2018). Motherhood in Early Bronze age Unterhautzenthal, Lower Austria. Archaeologia Austriaca 201 (2018) 71-134. https://doi.org/10.1553/archaeologia102s71

Schroeder, H., Margary, A., Szmyt, M., Theulot, B., Włodarczak, P. \& Rasmussen, S. et al. (2019). Unraveling ancestry, kinship, and violence in a Late Neolithic mass grave. PNAS 116, 10705-10710. https:// doi.org/10.1073/pnas.1820210116

Szabó, G. \& Hajdu, T. (2011). A mészbetétes edények díszítésének szimbolikája a bonyhádi vegyes rítusú bronzkori temetö embertani leleleteinek feldolgozása tükrében - Symbolism of the ornaments of encrusted pottery in the light of anthropological finds from the Bronze Age mixed-rite cemetery at Bonyhád. Anthropologiai Közlemények 52, 85-108. 
Viktória Kiss et al. $\bullet$ Methods and Opportunities in the Research of Bronze Age Communities

Szabó, G. (2017). Caught between the pincers of Oriental influences - Bronze Age cultures in Southern Transdanubia. In G. Kulcsár, G. V. Szabó, V. Kiss \& G. Váczi (eds), State of the Hungarian Bronze Age Research Conference. Proceedings of the conference held between 17th and 18th of December 2014 (pp. 285-308). Prehistoric Studies II. Budapest.

Szathmári, I., Guba, Sz., Kulcsár, G., Serlegi, G. \& Vágvölgyi, B. (2019). Füzesabony_Öregdomb Bronze Age tell settlement - New insights on the settlement structure. In K. P. Fischl \& T. Kienlin (eds), Beyond Divides - The Otomani-Füzesabony Phenomenon. Current Approaches to Settlement and Burial in the North-eastern Carpathian Basin and Adjacent Areas (pp. 351-268). UPA 345. Bonn.

Szécsényi-Nagy, A., Melis, E., Cheronet, O., Hajdu, T., Szeniczey, T. \& Dani, J. et al. (2021). Unraveling the genetic network of Bronze Age populations: complex genomic structures in 3000-800 BC East-Central Europe. In L. Orlando (ed.), ISBA9: 9th International Symposium on Biomolecular Archaeology June 1st4th 2021, (Toulouse, FRANCE), Abstract book (pp. 36-37). Toulouse.

Szeverényi, V., Hajdu, T., Marcsik, A. \& Kiss, V. (2020). Sacrifice, warfare, or burial? Middle Bronze Age "mass graves" from Érd and Makó, Hungary (2020). In H. Meller, R. Risch, K. W. Alt, F. Bertemes \& R. Micó (eds), Rituelle Gewalt - Rituale der Gewalt. 12. Mitteldeutscher Archäologentag vom 10. bis 12. Oktober 2019 in Halle (Saale) / Ritual Violence - Rituals of Violence. 12th Archaeological Conference of Central Germany, October 10-12, 2019 in Halle (Saale) (pp. 345-361). Tagungen des Landesmuseums für Vorgeschichte Halle 22. Halle (Saale).

Szeverényi, V. \& Kiss, V. (2018). Material evidence of warfare in Early and Middle Bronze Age Hungary. In M. Fernández-Götz \& N. Roymans (eds), Conflict Archaeology: Materialities of Collective Violence in Late Prehistoric and Early Historic Europe (pp. 37-49). Themes in contemporary archaeology - EAA Monographs Series. Oxford 2018.

K. Zoffmann, Zs. (2000). Anthropological sketch of the Prehistoric population of the Carpathian Basin. Acta Biologica Szegediensis 44, 75-79.

K. Zoffmann, Zs. (2015). A Mészbetétes kerámia népességének embertani leletei Szederkény és Versend lelőhelyekröl. Janus Pannonius Múzeum Évkönyve 53, 39-56. 